Table 1 Bureau of Labor Statistics Estimates of Occupetional Employment. 1968, and Projected Requirements, 1980, for College Graduates

\begin{tabular}{|c|c|c|c|c|c|}
\hline Occupation & $\begin{array}{c}\text { Estimated } \\
1968 \\
\text { employment }\end{array}$ & $\begin{array}{c}\text { Projected } \\
1980 \\
\text { requirements }\end{array}$ & $\begin{array}{l}\text { Per cent } \\
\text { change }\end{array}$ & & $\begin{array}{l}\text { Supply estimated } \\
\text { to be }\end{array}$ \\
\hline $\begin{array}{l}\text { Chemists } \\
\text { Dentists } \\
\text { Physicians } \\
\text { Physicists }\end{array}$ & $\begin{array}{r}130,000 \\
100,000 \\
295,000 \\
45,000\end{array}$ & $\begin{array}{r}200,000 \\
130,000 \\
450,000 \\
75,000\end{array}$ & $\begin{array}{l}55.7 \\
31.7 \\
53.1 \\
63.9\end{array}$ & & $\begin{array}{l}\text { Significantly below } \\
\text { requirements }\end{array}$ \\
\hline $\begin{array}{l}\text { Engineers } \\
\text { Geologists and geophysicists }\end{array}$ & $\begin{array}{r}1,100,000 \\
30,000\end{array}$ & $\begin{array}{r}1,500,000 \\
36,000\end{array}$ & $\begin{array}{l}40.2 \\
20.6\end{array}$ & \} & $\begin{array}{l}\text { Slightly short of } \\
\text { requirements }\end{array}$ \\
\hline \multirow{2}{*}{$\begin{array}{l}\text { Mathematicians } \\
\text { Life scientists } \\
\text { Teachers, elementary and } \\
\quad \text { secondary }\end{array}$} & $\begin{array}{r}70,000 \\
168,000\end{array}$ & $\begin{array}{l}110,000 \\
238,000\end{array}$ & $\begin{array}{l}60.5 \\
40.8\end{array}$ & & \multirow{2}{*}{$\begin{array}{l}\text { Significantly above } \\
\text { requirements }\end{array}$} \\
\hline & $2,170,000$ & $2,340,000$ & 7.8 & & \\
\hline
\end{tabular}

in 1980 , according to the NSF projection, but only 270,000 to 297,000 jobs. The surplus will be worst for engineers, among whom PhDs are likely to exceed by 40 per cent the number of jobs available ten years hence. Despite the present shadow of unemployment, however, it is predicted that scientists will enjoy a virtual balance between supply and demand in 1980 . Doctorate surpluses in other fields are for life sciences about 9 per cent; for mathematics about 10 per cent; and for sociologists 20 per cent. These surpluses are calculated from comparison of the middle of the ranges for supply and utilization of doctorates. The NSF's figures differ in detail, though not in broad outline, from those prepared by the Bureau of Labor Statistics for all college graduates (see Table 1).

The chief difference between the NSF's new projections and those it issued two years ago is a change in the assumptions about doctorate enrolment. Two years ago, the Office of Education, on whose assumptions the NSF study was based, guessed that graduate enrolment would have risen by 99 per cent in 1980 . The NSF now expects enrolment to rise by only 43 per cent. Smaller enrolment means a considerable reduction in the demand for graduate faculty, the chief source of employment of PhDs.

Why was the PhD surplus, present and emerging, not predicted earlier? In fact it was, notably by Allan $M$. Cartter, an economist who is now chancellor of New York University. The gist of Cartter's prediction is the demographic argument that a decline in the student body in the $1980 \mathrm{~s}$ - a consequence of the reduced fertility rates of recent years-will reduce the size of required faculty.

Why was Cartter treated like Cassandra? "Many people on the Washington scene, particularly in the Office of Education and NSF, but also among the university presidents and deans, felt that such projections were damaging to the national interest and would jeopardize federal funding for graduate education," Cartter said recently, arguing that it would be "much better to be objective and attempt to make the case for graduate support on its merits, rather than ride the scarcity myth another two or three years and then have the Congress react strongly once the apparent crisis was past. If the superb efforts that Phil Handler and the NSF board made in 1968 and 1969 to try and convince the Congress that graduate education should be funded for its own sake had been made five years earlier, I believe that our universities might not be in the same painful straits that they are now in."

\section{NATIONAL SCIENCE FOUNDATION More Mauling in House}

by our Washington Correspondent

THe House of Representatives has continued to rough up the National Science from the House Appropriations committee. The committee has recommended that in the fiscal year beginning this month the budget of the NSF be set at $\$ 582$ million, or $\$ 38$ million less than the amount requested by the Administration.

The House's first interference with the NSF's affairs was a rearrangement of its budget by the Science and Astronautics committee, which authorizes upper limits to the funds the Appropriations committee may recommend. In an unexpectedly authoritarian gesture, the inspiration for which is said to have stemmed from the committee's staff, the committee slashed the ambitious programme known as RANN (Research Applied to National Needs), restored the monies which had been pared from the NSF's educational programmes and compartmentalized the NSF budget to prevent these changes being reversed (see Nature, 231, 8; 1971). The House Appropriations comFoundation with a report just issued mittee has now followed these policies, recommending the full amounts authorized for the educational and institutional support programmes but cutting even further the funds for the group of programmes that includes RANN. In its report issued last week the committee also announced a cut of more than 10 per cent in the $\$ 257$ million requested for the support of individual research projects.

The decisions of the Appropriations committee have yet to pass the House but the authorization bill prepared by the Science and Astronautics committee sailed through last month with hardly a word of serious debate, unless the following interventions can be counted as such:

Mr Schmitz (a Republican from California): There has not been any discussion here about the social sciences. All the sales pitch on this bill has been on its more truly scientific aspects. As a former junior college social science instructor, I am quite familiar with the pseudo-scientific nature of many of the subjects encompassed under the broad heading of social sciences ... . [Referring respectively to studies of community organization, violence and demography.] Does that mean more for Cesar Chavez? Does that mean another Kerner report? Does that mean vote for Paul Ehrlich? ... I think not only Members of Congress but the people would be interested in finding out just what we are being drawn into under the umbrella of science.

Mr Gross (a Republican from Iowa): I do not care what colour of Mother Hubbard dress that is put over this socalled foundation ... This money will be spent on such esoteric and dubious projects as further studies to make sure that previous studies in social organization have not been howling flops, resulting in "imperfectly tested ideas" that would be extremely harmful if put to use .... Money would be used to find out how man has used his environment "around the world". That is where it is proposed to get into the \$2 billion a year spending on this business. More money will be spent to learn how people have adapted to urbanization. I suppose that will involve asking various people, "How do you like living in town?"

The Senate, on present form, has been kinder to the NSF. The subcommittee that handles the NSF's authorizations, chaired by Senator Edward Kennedy, last month recommended a budget of $\$ 703.5$ million for fiscal 1972 , an excess of some $\$ 83$ million above the President's request which may be designed to give the Senate some bargaining power against the lower sums recommended by the House. For good measure, Kennedy's committee took the unusual step of recommending an authorization for next year as well; for fiscal 1973 the committee wants the NSF to receive $\$ 900$ million. 